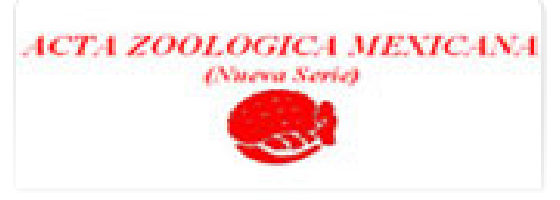

\section{Acta Zoológica Mexicana (nueva serie)} ISSN: 0065-1737

azm@ecologia.edu.mx

Instituto de Ecología, A.C.

México

García Aldrete, Alfonso N.; Mockford, Edward L.

A new species of Hemicaecilius Enderlein based on a male from Cuzco, Peru (Psocodea:

'Psocoptera': Lachesillidae)

Acta Zoológica Mexicana (nueva serie), vol. 27, núm. 2, agosto, 2011, pp. 419-423

Instituto de Ecología, A.C.

Xalapa, México

Available in: http://www.redalyc.org/articulo.oa?id=57520744014

How to cite

Complete issue

- More information about this article

Journal's homepage in redalyc.org

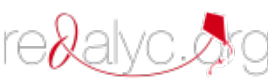

Scientific Information System Network of Scientific Journals from Latin America, the Caribbean, Spain and Portugal Non-profit academic project, developed under the open access initiative 


\title{
A NEW SPECIES OF HEMICAECILIUS ENDERLEIN BASED ON A MALE FROM CUZCO, PERU (PSOCODEA:'PSOCOPTERA': LACHESILLIDAE)
}

\author{
Alfonso N. García Aldrete ${ }^{1}$ \& Edward L. Mockford ${ }^{2}$ \\ ${ }^{1}$ Departamento de Zoología, Instituto de Biología, Universidad Nacional Autónoma de México, \\ Apartado Postal 70-153, 04510 México, D. F., MÉXICO. <anga@ibiologia.unam.mx> \\ ${ }^{2}$ School of Biological Sciences, Campus Box 4120, Illinois State University, Normal, Illinois, 61790- \\ 4120, U. S. A. <elmockf@ilstu.edu>
}

García Aldrete, A. N. \& E. L. Mockford. 2011. A new species of Hemicaecilius Enderlein based on a male from Cuzco, Peru (Psocodea: 'Psocoptera': Lachesillidae). Acta Zoológica Mexicana (n. s.), 27(2): 419-423.

ABSTRACT. A new species of Hemicaecilius Enderlein is here described and illustrated. It is based on a male collected near Machu Picchu, Peru, that constitutes the third specimen and the first male known in the genus. Its morphology confirms the closeness with Nadleria Badonnel \& García Aldrete, that had been established on basis of female characters. The holotype is deposited in the National Insect Collection, Instituto de Biología, Universidad Nacional Autónoma de México, Mexico City (coden CNIN).

Key words: Taxonomy, South America, neotropics, Psocoptera.

García Aldrete, A. N. \& E. L. Mockford. 2011. Una nueva especie de Hemicaecilius Enderlein basada en un macho de Cuzco, Perú (Psocodea:'Psocoptera': Lachesillidae). Acta Zoológica Mexicana (n. s.), 27(2): 419-423.

RESUMEN. Una nueva especie de Hemicaecilius Enderlein es aquí descrita e ilustrada. Está basada en un macho colectado cerca de Machu Picchu, Perú, que constituye el tercer ejemplar y el primer macho que se conoce en el género. Su morfología confirma la cercanía con Nadleria Badonnel \& García Aldrete, que había sido inferida con base en caracteres de la hembra. El holotipo está depositado en la Colección Nacional de Insectos, Instituto de Biología, Universidad Nacional Autónoma de México, México, D. F. (Coden CNIN).

Palabras clave: Taxonomía, Sudamérica, neotrópico, Psocoptera.

\section{INTRODUCTION}

The genus Hemicaecilius Enderlein is known from two female specimens, one of them is the holotype of $H$. bogotanus Enderlein (1903), of which only one fore- and one hind wing remain, mounted on a slide, deposited in the Museum für Naturkunde

Recibido: 18/08/2010; aceptado: 14/12/2010. 
der Humboldt Universitat in Berlin; the other specimen is the holotype of H. venezolanus García Aldrete \& Mockford (1997); the head, wings, legs and genitalia are mounted on a slide; the remains of the body are preserved in $80 \%$ ethyl alcohol. This specimen is deposited in the National Insect Collection, housed in the Instituto de Biología, Universidad Nacional Autónoma de México (coden: CNIN).

The information provided by the above two specimens, allowed García Aldrete \& Mockford (1997) to place Hemicaecilius in the family Lachesillidae, subfamily Lachesillinae, in which the genera Ectolachesilla García Aldrete, Hemicaecilius Enderlein, Lachesilla Westwood, and Nadleria Badonnel \& García Aldrete, are included (García Aldrete 2006, 2008). The genus was placed close to Nadleria, on the basis of a simple outer tine of the lacinial tip, an Rs-M crossvein present in the forewing of both genera, and fusion of the ovipositor valvulae with the ninth sternum in Hemicaecilius and most Lachesillinae. The closeness of the pair Hemicaecilius-Nadleria made predictable that the structural plan of the male of the former would be similar to the male of the later. Li Fasheng (2002), in his treatment of the Psocoptera of China, included in the Lachesillinae the genera Dicrolachesillus Li, Lachesilla, Zonolachesillus $\mathrm{Li}$, Ceratolachesillus $\mathrm{Li}$, Homoeolachesilla $\mathrm{Li}$, and Zangilachesilla $\mathrm{Li}$; some differences among these genera are indicated in the key, in Chinese (p. 1706), and in the English Abstract (p. 1921-1926). Lienhard \& Smithers (2002), recognized Homoeolachesilla in the Lachesillinae, and Lienhard (2003) synonymized Dicrolachesillus with Lachesilla. Zonolachesillus and Zangilachesilla would probably best be synonymized with Lachesilla, while Ceratolachesillus probably constitutes a distinct genus, but further study is needed to validate the changes.

In this paper we study the third specimen known of Hemicaecilius, the first male known in the genus.

\section{MATERIAL AND METHODS}

One male specimen was available for study. It is here described and illustrated; it was treated in the usual way for mounting on a slide in Canada Balsam; the usual measurements, stated in $\mu \mathrm{m}$, were taken with an AO filar micrometer (measuring units $1.36 \mu \mathrm{m}$ for wings, and $0.53 \mu \mathrm{m}$ for other parts, see García Aldrete 2006). Color was recorded by placing the whole specimen, before dissection, under a microscope, illuminated with white, cold light, at 80X. The type is deposited in the National Insect Collection, Instituto de Biología, Universidad Nacional Autónoma de México, México City (coden CNIN).

Hemicaecilius cuzcoensis n. sp. (ð).

Color (in $80 \%$ ethyl alcohol). Body dark chocolate brown. Compound eyes black, ocelli hyaline, with ochre centripetal crescents. Maxillary palps more pigmented than 


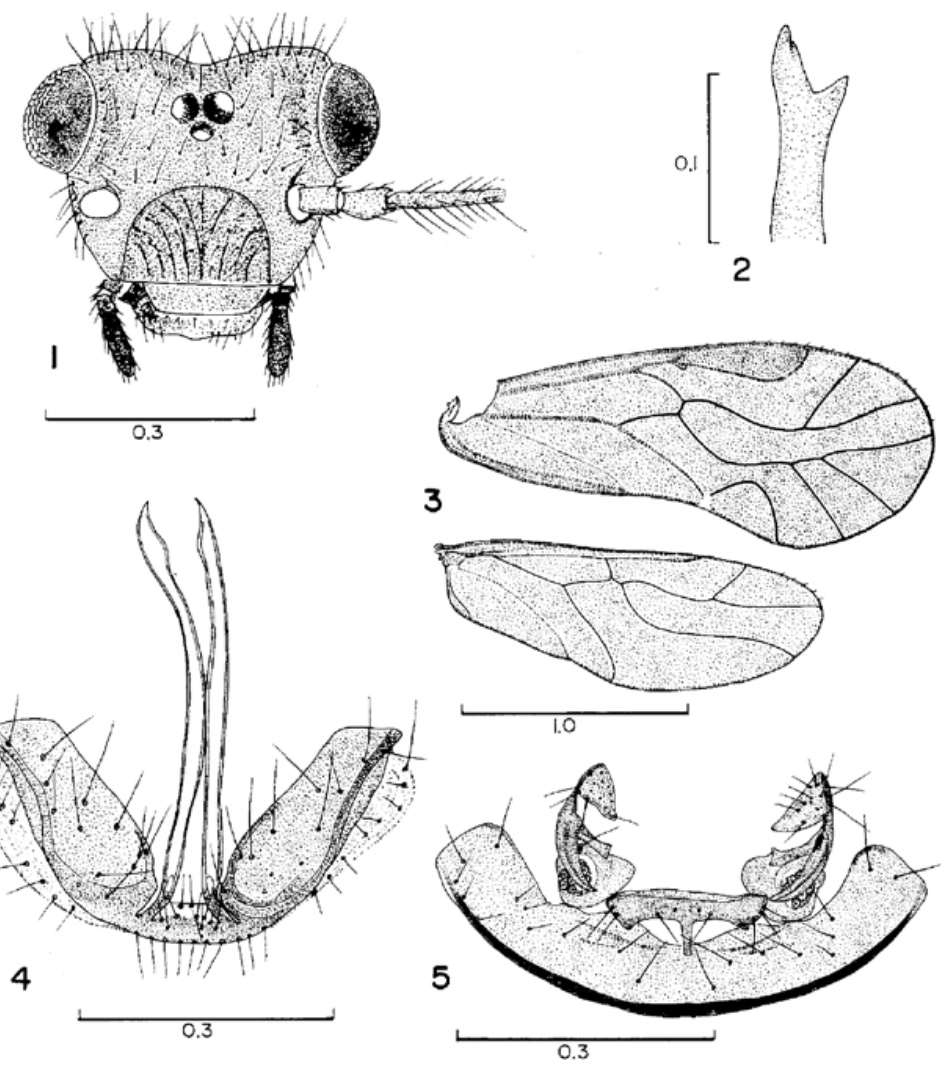

Figures 1-5. Hemicaecilius cuzcoensis n. sp. (ঐ). 1. Front view of head. 2. Apex of lacinia. 3. Foreand hind- wings. 4. Hypandrium and claspers. 5. Clunium, paraprocts and epiproct. Scales in $\mathrm{mm}$.

rest of the body. Antennae and legs dark brown. Wings dark brown, opaque. Abdomen with dark, reddish brown, transverse subcuticular rings, less pigmented ventrally.

Morphology. Ocelli present, lateral ones much larger than median one (Fig. 1). Lacinial tips bifid, outer cusp bidentate, larger than inner one (Fig. 2). Head vertex obtusely concave; epicranial sulcus without lateral arms. Compound eyes slightly below level of vertex; epistomal sulcus well defined. Five distal inner labral sensilla, a central placoid, flanked at a distance by a pair trichoid-placoid. Forewing with small setae along margin and veins, pterostigma wider posteriorly, areola postica wide, almost triangular; Rs-M veins joined by a crossvein (Fig. 3). Hindwing with 
row of small setae along margin in cell R3 (Fig. 3), Rs-M veins fused for a distance (Fig. 3). Pretarsal claw with one prapical denticle and slender pulvillus. Hypandrium small, fused on the sides to claspers; proximal halves of these, robust, setose, distal halves slender, elongate, straight, preapically dilated, terminally acuminate (Fig. 4). Paraprocts elongate, with a mesal, sickle-shaped prong: "handle" short, truncate, and distal half basally wide, narrowing to end, acuminate (Fig. 5); sensory fields circular, with 10 trichobothria issuing from basal rosettes and a marginal one without basal rosette (Fig. 5). Epiproct with a slender, straight, posterior truncate projection (Fig. 5). Phallic apodemes not observed (see Type material).

Measurements. FW: 2087, HW: 1697, F: 356, T: 672, t1: 212, t2: 100, ctt1: 17, Mx4: 89, f1: 184, f2: 171, f3: 148, f4: 116, f5: 72, f6: 69, f7: 69, f8: 67, f9: 58, f10: 59, f11: 70, IO: 323, D: 159, d: 98, IO/D: 2.03, PO: 0.61 .

Type material. PERU. Cuzco. Aguascalientes, near Machu Picchu, on ravine above thermal baths, beating vegetation with dead leaves $\left(13^{\circ} 09.291^{\prime} \mathrm{S}\right.$ : $\left.72^{\circ} 31.381^{\prime} \mathrm{W}\right)$, 8.VIII.2005. A. N. García Aldrete. Holotype $\widehat{\jmath}$. Head, right side wings and legs and genitalia dissected and mounted on a slide. Phallosome lost in preparation. Remains of body preserved in $80 \%$ alcohol.

Etymology. The specific name refers to the Peruvian Department of Cuzco, where the holotype was collected.

\section{DISCUSSION}

The specimen here described and illustrated risks the eventual creation of a synonymy with one of the described species, known only from females; it was assigned to Hemicaecilius because the fore- and hind- wings are strikingly similar to the foreand hind- wings of $H$. bogotanus Enderlein, and of $H$. venezolanus García Aldrete $\&$ Mockford; the membrane of the forewing is glabrous, without areas differentially pigmented, which excludes the possibility of assigning the specimen to Nadleria. Also, the male genitalia in species of Nadleria is virtually identical to the male genitalia in species of Lachesilla in the group pedicularia, and in the specimen studied the distal halves of the claspers are extremely long, this and the peculiar paraproctal prongs also exclude the possibility of the specimen belonging in Nadleria. The morphology of the male Hemicaecilius cuzcoensis n. sp., confirms the views of García Aldrete \& Mockford (1997), concerning the position of Hemicaecilius in the subfamily Lachesillinae: it is close to Nadleria on basis of the Rs-M crossvein in the forewing; similar hypandrium-claspers plan, although in Hemicaecilius the distal halves of the claspers are extremely long and distally acuminate; epiproct with a posterior projection, and paraprocts with an acuminate, mesal prong (for male terminalia of Nadleria, see Mockford, 1985 and García Aldrete, 1996). These characters in Hemicaecilius, other than the Rs-M crossvein in the forewing, and the long, distal halves of the clasp- 
ers, are also shared with species group pedicularia of Lachesilla, which is closest to Nadleria. It is likely that eventually Lachesilla will have to be restricted to species group pedicularia, with the pair Hemicaecilius-Nadleria as sister group.

\section{LITERATURE CITED}

Enderlein, G. 1903. Zur Kenntniss amerikanischer Psociden. Zoologische Jahrbücher (Abteilung Systematik), 18: 351-364.

García Aldrete, A. N. 1996. A new species of Nadleria (Psocoptera: Lachesillidae) from the Tambopata Reserved Zone, Madre de Dios, Peru. Entomological News, 107: 28-32.

García Aldrete, A. N. 2006. New genera of Psocoptera (Insecta), from Mexico, Belize and Ecuador (Psoquillidae, Ptiloneuridae, Lachesillidae). Zootaxa, 1319: 1-14.

García Aldrete, A. N. 2008. Ectolachesilla: A new genus of Lachesillidae (Insecta: Psocoptera) from Amazonas, Brazil. Entomological News, 119: 251-255.

García Aldrete, A. N. \& E. L. Mockford. 1997. The position of Hemicaecilius (Psocoptera: Lachesillidae) and description of a new species from Venezuela. Entomological News, 108: 102-106.

Li Fasheng. 2002. Psocoptera of China. Science Press. Beijing. 2 Volumes. XLVI + 1976 pp.

Lienhard, C. 2003. Nomenclatural amendments concerning Chinese Psocoptera (Insecta), with remarks on species richness. Revue Suisse de Zoologie, 110: 695-721.

Lienhard, C. \& C. N. Smithers. 2002. Psocoptera (Insecta): World Catalogue and Bibliography. Instrumenta Biodiversitatis V. Muséum d'histoire naturelle, Genève, Switzerland. 745 pp.

Mockford, E. L. 1985. Systematics of the Genus Nadleria (Psocoptera: Lachesillidae) with Description of a New Species and Hypotheses on Evolution of Male External Genitalia in the Family Lachesillidae. Annals of the Entomological Society of America, 78: 94-100. 